інноваційну діяльність дошкільного педагога, формує педагогічне мислення, демократичний стиль майбутньої професійної діяльності.

Аналіз діяльності студентів під час різних видів практики засвідчує, що ця технологія вчить успішно відбирати потрібну інформацію 3 різних першоджерел, інтегрувати отримані дані задля досягнення поставлених завдань і шукати інноваційні способи їх використання. Практика засвідчує, що використання цієї технології стимулює інтерес студентів до інноваційної діяльності, переконує в необхідності набуття навичок проектування і моделювання нових підходів до організації навчально-виховного процесу в дошкільних навчальних закладах.

Отже, констатуємо, що метод проектів ефективно впливає на удосконалення професійної підготовки майбутніх вихователів дошкільної освіти, стимулює інтерес студентів до інноваційної діяльності. Викладачі ВНЗ повинні стимулювати студентів до інноваційного пошуку, самостійного педагогічного мислення, самоосвіти та самовдосконалення протягом усього життя. Метод проектів $\epsilon$ одним із сучасних ефективних методів, використовуваний у сучасній професійній освіті. У його основі лежить особистісно зорієнтований підхід до навчання й виховання дітей і молоді. Він розвиває пізнавальний інтерес студентів до реалізації різних галузей знань в освітніх закладах, формує навички співпраці, дослідницький пошук педагогів. Важлива роль під час використання такого методу належить розвитку творчої уяви студентів і подолання їхньої психологічної інерції. Зазначене визначає необхідність подальшого пошуку шляхів розв'язання цієї проблеми.

\title{
Література
}

1. Біла книга національної освіти України / Т. Ф. Алексєєнко, В. М. Аніщенко, Г. О. Балл [та ін.]; за заг. ред. акд. В.Д. Кременя; НАПН України - К.: Інформ. системи, 2010. - 342 с. 2. Інноваційні педагогічні технології. - К.: ІЗМН, 2004. - 546 с. 3. Метод проектов в университетском образовании: [сб. науч.-метод. статей]. - Вип. 6. / [под общ. ред. М. А. Гусаковского]. - Минск : БГУ, 2008. - 244 с. 4. Юсуфбекова Н. Общие основы педагогической инноватики: опыт разработки теории инновационных процессов в образовании / Н. Юсуфбекова. - М., 1991. - 41 с.

\section{ФОРМУВАННЯ ПРОФЕСІЙНОГО СВІТОГЛЯДУ МАЙБУТНЬОГО ВИКЛАДАЧА ЗАРУБІЖНОЇ ЛІТЕРАТУРИ ЯК МЕТА І СОЩАЛЬНО ЗНАЧУЩИЙ РЕЗУЛЬТАТ ЙОГО ФАХОВОЇ ПІДГОТОВКИ У ВИЩОМУ НАВЧАЛЬНОМУ ЗАКЛАДІ}

Романець В. М. Формування професійного світогляду майбутнього викладача зарубіжної літератури як мета і соціально значущий результат його фахової підготовки у вищому навчальному закладі.

У статті подано результати теоретико-експериментальної роботи з формування професійного світогляду майбутнього викладача зарубіжної літератури в умовах євроінтеграції та глобалізації освітньо-наукового простору вищої школи. Особливу увагу приділено висвітленню концептуальних засад дослідження.

Ключові слова: викладач зарубіжної літератури, професійна підготовка майбутніх викладачів зарубіжної літератури, формування професійного світогляду.

Романец В. М. Формирование профессионального мировоззрения будущего преподавателя зарубежной литературы как цель и социально значимый результат его подготовки в вузе.

В статье освещены результаты теоретико-экспериментальной работы по формированию профессионального мировоззрения будущего преподавателя зарубежной литературы в условиях 
евроинтеграции и глобализации научно-образовательного пространства высшей школы. Особое внимание уделяется отражению концептуальных основ исследования.

Ключевые слова: преподавателя зарубежной литературы, профессиональная подготовка будущих преподавателей зарубежной литературы, формирование профессионального мировоззрения.

Romanets V. M. The formation of professional ideology of the future lecturer of foreign literature as aim and social significant result of his specialized preparation in high education establishment.

The article presents the results of theoretical analysis of the problem of formation of professional worldview of the future teacher of foreign literature in condition of multicultural society. Particular attention is given to coverage conceptual principles of organization of this process by grounding the leading principles of the course «Foreign literature».

Key words: teacher of foreign literature, professional training the future teachers of foreign literature, formation of professional worldview.

3-поміж стратегічних напрямів модернізації національної системи освіти, окреслених у Законах України «Про освіту», Концепції національного виховання та Національній доктрині розвитку освіти України у XXI столітті, одним із актуальних постає завдання світоглядної підготовки майбутніх викладачів. Це зумовлено тим, що в умовах нової соціально-економічної та культурної політики нашої держави, спрямованої на інтеграцію в європейський та світовий науково-освітній простір, оновлена система організації професійної підготовки майбутніх викладачів покликана не тільки врахувати їхні природні здібності, але й створити сприятливі умови для творчого розвитку та формування повноцінної особистості громадянина України, відтворити його національний характер, спосіб мислення та гуманістичний світогляд (I. Бех, I. Зязюн, В. Кузь, О. Сухомлинська).

Натомість послаблення соціального контролю значно знижує не тільки громадську активність підростаючого покоління майбутніх викладачів, а також гальмує заходи щодо педагогічного керівництва процесом формування їхньої особистості як свідомого громадянина й фахівця. Як наслідок, нині надзвичайно важливого значення набуває не тільки розроблення інноваційної педагогічної системи цілеспрямованого, розрахованого на тривалий час виховання в майбутніх викладачів соціальних потреб, особливо пов'язаних із сприйняттям та відтворенням культурних цінностей, а й їхньої відповідної професійної підготовки до ефективної організації культурно-дозвіллєвої діяльності учнів, з урахуванням нових тенденцій розвитку соціокультурної сфери українського суспільства.

Методологічне підгрунтя дослідження феномену світогляду як способу духовнопрактичного, а не тільки теоретичного вивчення дійсності та формування суспільної й індивідуальної самосвідомості, а також його дефінітивної характеристики окреслені в наукових працях В. Афанасьєва, Р. Арцишевського, Є. Бистрицького, М. Гончаренка, В. Горського, Н. Патова, О. Спіркіна, В. Шинкарука. Виокремленням елементів світогляду, його типів, рівнів, змістових характеристик у різні часи опікувалися такі дослідники, як Р. Арцишевський, В. Горинь, О. Срмолов, М. Ковальзон, П. Копнін та ін. Багатоаспектність проблеми формування художнього світогляду особистості знайшла своє відображення в наукових працях із методології мистецтвознавства (Ю. Афанасьєв, Л. Закс, А. Зись, М. Каган, Л. Столович), психології художнього сприйняття (Л. Виготський, С. Крупнік, О. Леонтьєв, Д. Леонтьєв, С. Раппопорт, П. Якобсон), поліхудожнього виховання особистості (Л. Масол, Н. Миропольська, Л. Предтеченська, Г. Шевченко).

Психолого-педагогічні основи становлення та функціонування світогляду особистості висвітлено в працях М. Ашманіса, Л. Божович, І. Лернера, Н. Менчинської, Е. Моносзона, К. Платонова, К. Шуртакова. На важливій ролі художньої літератури та мистецтва в розвитку світоглядної свідомості фахівця наголошується в дослідженнях Є. Володіна, В. Іванова, В. Мазепи, В. Малахова, В. Смікал, Д. Ханіна, Т. Шуртакової. 
Водночас проблема формування професійного світогляду майбутнього викладача зарубіжної літератури в ході опанування ним фахових дисциплін, їх міжпредметного зв'язку з гуманітарними й педагогічними дисциплінами, не була предметом самостійного дослідження й потребує подальшого розроблення.

3 огляду на актуальність, теоретичну значущість означеної проблеми, метою статті є висвітлення особливостей формування професійного світогляду майбутнього викладача зарубіжної літератури в умовах євроінтеграції і глобалізації суспільства, специфіки означеного феномену.

Розглядаючи сутність світогляду як суспільного явища, ми грунтувалися насамперед на позиціях соціологічного, культурологічного й аксіологічного підходів до його вивчення, що виходять із соціально-історичної зумовленості індивідуальної свідомості і світогляду, тобто розглядали його специфіку насамперед крізь призму соціальної і професійної структури суспільства. У цьому зв'язку ми поділяємо точку зору тих авторів (А. Баталов, А. Демичев, О. Цокур та ін.), які довели, що саме професійна свідомість значною мірою визначає формування особистісного світогляду фахівця, оскільки специфічне суспільнокультурне середовище відповідної професії породжує адекватну їй професійну свідомість, мислення і світогляд конкретного індивіда. Із урахуванням належності індивіда до того чи того рівня соціально-професійної структури суспільства, у нього формуються відповідні професійно-орієнтовані світоглядні уявлення різної якості - «від марновірств, забобонів й архаїчних звичаїв, що мають силу несвідомого інстинкту, до витончених інтелектуальних, елітарних форм творчого втілення світоглядних шукань» [1, с. 20].

Вихідна опозиція «людина - світ професії» відбиває специфіку професійного світогляду, що конкретизується в низці приватних опозицій, таких, як «людина - предмет професійної праці», «людина - професійне співтовариство», «людина - історія професії». Ця опозиція фіксує, з одного боку, протиставлення суб'єкта професійної діяльності й професійного середовища, а з іншого - складну систему їх взаємин. Оскільки предметом професійного світогляду $є$ взаємодія соціального суб'єкта 3 об'єктом професійної праці, то «опосередкованою ланкою у світоглядному відображенні є завжди суб'єкт-об'єктна чи об'єкт-суб'єктна співвіднесеність» [1, с. 45].

3 цього приводу німецький дослідник К. Хаазе справедливо зауважує, що розвиток професійного світогляду особистості «е не тільки результатом власного досвіду й теоретичного розуміння. Він пов'язаний із опанованими соціальними й іншими професійними відносинами». У суспільстві створюється й функціонує, так би мовити, загальне світоглядне силове поле, що пронизує собою свідомість усіх членів суспільства, визначаючи їхні загальні саморефлексії, світоглядні настанови й орієнтири. Загальне світоглядне силове поле створює панівний світогляд, породжуваний сталим типом соціальності [2, с. 13].

Для нашого дослідження важливими були також основні положення культурологічного підходу, що стосуються розуміння професійного світогляду як закономірного результату всього попереднього процесу розвитку сфери професійної культури. Це зумовлено тим, що значна частина професійного світогляду формується в межах конкретної культури, домінуючих стереотипів мислення, мови тощо. У цьому розумінні очевидна правомірність виокремлення константної і динамічної частин професійного світогляду, перша 3 яких «виникає під впливом уже сформованого способу виробництва, духовної культури, що підростаюче покоління застає вже готовими, та інша частина - динамічна, котра складається за час життя цього покоління, залежить цілком від його досвіду» [2, с. 33].

Під час аналізу сутності феномену професійного світогляду ми також ураховували положення аксіологічного підходу, що надає великого значення вивченню його ціннісного складника, внаслідок того, що під час формування професійного світогляду найважливішим етапом є оцінка індивідом подій, що відбуваються, і явищ. Зокрема, спираючись на позицію В. Дильтея про те, що основа світогляду - деяка картина світу, що $\epsilon$ результатом закономірної послідовної роботи нашого пізнання [2, с. 133], ми 
дотримувалися його погляду про те, що сума знань сама по собі не утворює професійного світогляду, оскільки для того, щоб знання стали елементом останнього, вони мають бути опосередковані особистісним ставленням, мають бути оцінені. На основі цієї якості знань формується ядро професійного світогляду - відповідні переконання особистості професіонала, що $є$ вищим виявом іiі професійної спрямованості і становлять собою глибоку й обгрунтовану віру в професійні ідеали і принципи. У свою чергу, професійні переконання як «активна форма висловлення, тобто визначена інтелектуальна (а також залежно від змісту висловлення, політична, моральна, естетична тощо) позиція», регулюють професійну діяльність людини як фахівця. Окрім того, найважливішою характеристикою професійного світогляду є його зорієнтованість на дію, спрямованість на практичне фокусування: «...Світогляд $\epsilon$ не простим знанням, не простим переконанням, а особливим ідеальним явищем, що регулює відносини між знаннями і практичною перебудовою світу. Тому світогляд - це не просте світорозуміння, але й знаряддя світоперетворення. Це практичне знання, практична теорія» [2, с. 135].

Із цього випливає, що процес опанування професійних знань індивідом, їх зарахуванням до структури професійного світогляду пов'язаний з усвідомленням, інтересом й емоційновольовим ставленням до знання. Професійний світогляд - це не просте пізнання фахівцем сфери професійної дійсності, що оточує, а насамперед ії оцінка, вироблення особистісного до неї ставлення, що, будучи не «функціональним», а саме «особистісним» утворенням, «психологічно виявляється у формі почуття, чи прагнення, чи ідеологічно оформленого оцінного судження. Те саме ставлення знаходить відбиття у сфері і почуттів, i волі, i мислення». Як наслідок, ціннісний складник професійного світогляду, компонентами якої $є$ думки, переконання, ціннісні орієнтації, ідеали, безпосереднім чином визначає вчинки й дії особистості професіонала.

У науковій літературі останніх років подається умовивід, що різні професії формують специфічні професійні типи світогляду: політичний, економічний, інженерний, математичний, біологічний, художній, педагогічний, філософський тощо. На основі того, що мислення і свідомість тісно пов'язані 3 професійною діяльністю фахівця і детерміновані нею, дедалі частіше висувається гіпотеза про існування особливого професійного типу світогляду.

Однак, важко уявити людину, світогляд якої вичерпувався б тільки професійною сферою. Подібного роду неповноцінна освіта цілком суперечила б інтегративній специфіці самого поняття світогляду. Професійний складник, безумовно, впливає на становлення індивідуального світогляду, але існує не інакше, як його частина, така сама, як ідеологічна, моральна, естетична, релігійна й інші. Не можна також заперечувати, що перераховані вище інформаційні блоки світогляду перебувають у найскладнішій взаємодії, взаємовпливі. Баланс між ними і їхнім змістовним наповненням створюють неповторний, унікальний світогляд конкретної людини.

Так, А. Баталов пов'язує професію насамперед із предметно-цільовим і технологічним відокремленням: професія - це диференціація і спеціалізація знання і діяльності суб'єктів, що використовують певні технічні пристрої. Професія є предметом потреби, сферою застосування здібностей, способом самореалізації i самоствердження людини. Професіоналізація занять супроводжується соціальним відокремленням людей, що належать до певної професійної групи. Професія $є$ складним утворенням, це «рід занять, форма забезпечення існування, соціотехнічний процес зі своєрідним механізмом, соціальний інститут, спосіб ставлення людини до природи, до інших людей, до самої себе, предмет іiі потреби і самоствердження» [1, с. 52].

Складність тлумачення поняття «професійний педагогічний світогляд» випливає 3 двоїстої природи освіти: реальна педагогічна дійсність, освітня практика, з одного боку, та ідеї, погляди, теорії, концепції - $з$ іншого. Іншими словами, освіта - це одна зі сфер життя суспільства, що існує одночасно з економікою та іншими галузями, це і світ ідей, уявлень, теорій, деяка духовна реальність, невіддільна від реальності першого роду, але в 
деяких аспектах така, що має свою специфіку.

Виходячи 3 практики освітньої діяльності, науковці (Т. Железнова, А. Касьян, О. Цокур) уважають, що «вихователь-педагог покликаний долучати своїх вихованців до тих цінностей, які він сам шанує і які присутні в кожному кроці його життя. Вище мистецтво вихователя саме в тому й полягає, щоб зробити для вихованців привабливішими вищі ціннісні сенси так, щоб кожен зміг самостійно відкрити їх як свої власні, безкомпромісно дорожити ними і привчати себе залишатися вірним їм за будьяких негод, труднощів і випробувань» [4, с. 11]. Особливість професійного педагогічного світогляду полягає в тому, що викладач - не тільки носій світоглядної культури, але й втілювач ii у шкільне середовище через свою професійну діяльність; звідси висока «світоглядна відповідальність» педагогічного університету в процесі підготовки вчительських кадрів. Для професійного педагогічного світогляду характерна дієвість у динаміці, оскільки вчитель за характером своєї діяльності, працюючи в конкретний історичний період, повинен бути спрямований на перспективу, на майбутнє своїх учнів.

Педагогічний світогляд - це розуміння сутності світу педагогічних явищ, ставлення особистості до нього і свого місця в ньому. Це система переконань, цінностей, поглядів на педагогічний процес, його розуміння, самостійна, особистісна позиція, що допомагає організації й осмисленню своєї професійної діяльності на основі сучасних наукових досліджень і надає їй продуктивного, ефективного характеру. Водночас передбачається чітке розмежування понять «педагогічний світогляд», що належить до ненаукового повсякденного світогляду, властивого широкому колу осіб: батькам, лікарям, діячам культури і мистецтва, і «професійний педагогічний світогляд» як науковий світогляд, що грунтується на фундаментальних знаннях філософських, психолого-педагогічних, а також економічних і правових дисциплін, що захищають питання школи, родини, дитинства i материнства. Професійний педагогічний світогляд тлумачиться як система поглядів, переконань, цінностей та ідеалів учителя, що динамічно розвивається, заснованих на філософських, психолого-педагогічних, економічних, правових наукових знаннях, що визначають спрямованість його професійної діяльності і знаходять своє відображення в особистісній позиції.

Вивчення наукової літератури засвідчує, що педагогічний світогляд - надзвичайно складне і багатоаспектне явище, що здавна піддавалося і піддається осмисленню в різних наукових галузях знання у статусі одного з фундаментальних понять. При цьому його вивченню присвячено безліч досліджень, здійснюваних 3 позицій різних підходів: соціально-філософського, історичного, аксіологічного, культурологічного, психологічного, педагогічного. Дотримуючись методологічної позиції, що жоден конкретнонауковий підхід не дає адекватного уявлення про світогляд як про цілісне явище, ми сконцентрували теоретичний пошук на розкритті діалектики понять «світогляд»- «професійний світогляд» - «професійний світогляд викладача зарубіжної літератури».

Доведено, що поняття «професійний світогляд викладача зарубіжної літератури» $є$ похідним від родового поняття «професійний світогляд». Типологічно світогляд викладача як фахівця високоінтелектуальної сфери професійної діяльності, безумовно, належить теоретичному рівню. Його особливість полягає в тому, що він поєднує в собі риси наукового (оскільки він професійний) і художнього (оскільки він літературний) світогляду. У ньому виявляються одночасно почуття і розум; він вимагає природного натхнення, широти кругозору і спеціального пізнання, що здобуваються тільки шляхом тривалого вивчення рідної й іноземної мов, різних сфер реальної дійсності і глибоких міркувань. Поєднання знань i творчого натхнення створює мистецтво педагогічної діяльності викладача зарубіжної літератури. Професійні знання, що складають основу його світогляду, мають всі ознаки наукової теорії (мовознавства, літературознавства тощо), а мистецтво викладання особливим чином забарвлює цю наукову теорію.

Професійний світогляд викладача зарубіжної літератури - це система узагальнених 
поглядів на світ його професії, яка динамічно розвивається, її роль і місце в соціумі, що визначають його ставлення до сфери міжкультурної, іншомовної і міжособистісної комунікації і до самого себе як суб’єкта педагогічної діяльності, а також зумовлена цими поглядами сукупність професійних переконань, ідеалів, принципів пізнання і дій, в основу яких покладено художньо-естетичний смак і педагогічну майстерність, соціальну зрілість і відповідальність кваліфікованого фахівця.

Професійний світогляд викладача зарубіжної літератури - це вищий синтез його професійних знань, емоційно-ціннісних оцінок і практичного досвіду щодо реалізації літературознавчої й педагогічної компетентностей. На цій основі, виходячи зі специфіки професійної праці викладача зарубіжної літератури й вимог до його особистості як особливого типу фахівця-професіонала, ми обгрунтувати структуру його професійного світогляду у складі інтелектуального, емоційно-ціннісного і діяльнісно-практичного компонентів, що тісно взаємодіють між собою, утворюючи цілісну систему. Крім того, упродовж формувального експерименту, проведеного на базі факультету романогерманської філології ОНУ ім. І. І. Мечникова впродовж 2008-2012 рр. було доведено, що формування професійного світогляду майбутнього викладача зарубіжної літератури відбуватиметься ефективніше за таких дидактичних умов, як-от: використання комплексу методів структуризації, систематизації та інтеграції культурологічних, поліхудожніх та історико-педагогічних знань студентів задля формування в них цілісної художньої та педагогічної картини світу; застосування психотехнічних та соціоігрових методів навчання фахових дисциплін задля актуалізації художньо-смислової рефлексії студентів та концептуалізації їх емоційно-ціннісного ставлення до творів зарубіжної літератури як складника педагогічної культури; моделювання ситуацій діалогізації професійнопедагогічного спілкування, що враховують плюралістичний характер європейського та світового освітнього простору.

Отже, у процесі власних спостережень за прикінцевими результатами професійної підготовки майбутнього викладача зарубіжної літератури ми дійшли висновку, що його професійний світогляд, будучи складноструктурованим новотвором його особистості як фахівця, разом з компонентною структурою має свій особливий функціональний механізм, що дозволяє не тільки диференціювати його сутність, але й забезпечувати автономність за допомогою реалізації сукупності відповідних функцій: просвітницької, розвивальної, виховної, прогностичної, організаційної, культурологічної. Перспективи подальшого дослідження проблеми вбачаємо в розробленні оновленого змісту світоглядної підготовки майбутніх викладачів зарубіжної літератури.

\section{Література}

1. Баталов А. А. Профессиональное мышление: Методологический аспект / А. А. Баталов. - М. : Наука, 1988. - 127 с. 2. Мировоззренческая культура личности: философские проблемы формирования / отв. ред. В. П. Иванов. - К. : Наук. думка, 1986. - 292 с. 3. Макарова Л. Н. Преподаватель высшей школы: индивидуальность, стиль, деятельность: [монография]: [в 2 ч.] / Л. Н. Макарова. - Тамбов : Изд-во ТГУ, 2000. Ч. 2. - 2000. - 142 с. 4. Цокур О. С. Категорія педагогічної свідомості у професійній підготовці майбутнього вчителя: дис. ... док. пед. наук: 13.00.01; 13.00 .04 / Ольга Степанівна Цокур. Одеса, 1998. - 397 с.

УДК 371. 134-057.875:81’243

I. В. Ромащенко, кандидат пед. наук, доцент, Академія муніщипального управління (м. Київ)

\section{ПРОФЕСІЙНА КУЛЬТУРА ВИКЛАДАЧА ЯК УМОВА САМОРЕАЛІЗАЦІЇ ПЕДАГОГА}

Ромащенко І. В. Професійна культура викладача як умова самореалізації педагога.

У статті доведено актуальність питання культури професійного спілкування викладача, сформульовано основні вимоги до професійного мовлення на сучасному етапі. Автором визначена 